\title{
Vascular Endothelial Growth Factor Concentration in Brain of Rat Treated with Anaerobic Exercises
}

\author{
Rostika Flora, Muhammad Zulkarnain, Yuliana \\ Faculty of Medicine, Universitas Sriwijaya, Indonesia
}

\begin{abstract}
Article Info
Article history:

Received Jul 24, 2015

Revised Aug 20, 2015

Accepted Aug 30, 2015

\section{Keyword:}

Anaerobic

Angiogenesis

Brain tissues

Physical activities

Vascular endhothelial

ABSTRACT

Anaerobic exercise is a high-intensity exercise that needs quick energy supplies obtained in a very short time. However, this exercise may result in tissue hypoxia which is characterized by the increase of HIF-1 $\alpha$ concentration. The presence of HIF-1 $\alpha$ will induce the secretion of VEGF and, eventually, trigger angiogenesis. Nevertheless, it is still unclear whether anaerobic exercise will also cause hypoxia in which this condition will increase the concentration of VEGF in brain tissues. The aim of this study was to find out the effect of anaerobic exercise frequency towards VEGF concentration of Wistar rat brain tissues. Brain tissues were taken from rats treated with anaerobic exercise using treadmill. This exercise was given in different frequencies; one time, three times, and seven times a week. The data collected were analyzed using independent t-test. The results of this study showed that anaerobic exercise done once a week could significantly increase VEGF concentration $(\mathrm{p}<0.05)$ if compared with the one in control group $(95.21 \pm 31.99$ v.s. $63.36 \pm 11.01 \mathrm{pg} / \mathrm{mL})$. Meanwhile, VEGF concentration of treatment groups given exercise three times a week $(47.97 \pm$ $10.68 \mathrm{pg} / \mathrm{mL})$ and seven times a week $(40.56 \pm 13.98 \mathrm{pg} / \mathrm{mL})$ showed a significant decrease if compared with that of control group $(63.36 \pm 11.01$ $\mathrm{pg} / \mathrm{mL}$ ). Anaerobic exercise affected VEGF concentration as an indicator of angiogenesis in brain tissue of wistar rats.
\end{abstract}

Copyright () 2015 Institute of Advanced Engineering and Science. All rights reserved.

\section{Corresponding Author:}

Rostika Flora,

Department of Biomedical Science, Faculty of Medicine,

Universitas Sriwijaya,

Palembang, South of Sumatera, Indonesia.

Email: rostikaflora@unsri.ac.id

\section{INTRODUCTION}

Anaerobic physical exercise is a high-intensity activity acquiring immediate energy in a very short time, but it cannot be done continuously [1]. Anaerobic environment will trigger the accumulation of HIF-1 $\alpha$ in tissues. When hypoxia occurs, HIF-1 $\alpha$ will translocate to cell nuclei to make dimerisation with HIF-1 $\beta$ to form HIF-1 [2]. Through activation of HIF-1, the expression a number of genes, including Vascular Endothelial Growth Factor (VEGF), will be increased in order to lessen cell dependence to oxygen and to elevate oxygen supply to tissues as well.

VEGF is an essential regulator in developing new blood cappillaries (angiogenesis) [3]. The development of these new cappillaries appears as a response to meet oxygen demands in hypoxic muscle tissues. Other studies conducted both in vivo and in vitro had proved that VEGF was involved in the regulation of angiogenesis process [4]. A study of Flora et al indicated that there was an increase in VEGF concentration of cardiac muscle tissues of rats treated with anaerobic physical exercises. The increase of VEGF concentration in anaerobic groups was higher than that of aerobic ones [5].

Besides cardiac muscles, brain is one of the vital organs which also works hard to maintain body 
balance when physical exercises occur. Other previous related study stated that angiogenesis occurred in brain motor cortex tissue of rats that were given aerobic physical exercise [6]. As previously mentioned, it is said that anaerobic physical exercise can cause angiogenesis in brain tissues, but this statement is still debatable [7]. In addition, the number of studies regarding the effect of anaerobic physical exercises towards angiogenesis is still small. In normal brain tissue, it is still unexplained whether or not anaerobic physical activities could also increase the secretion of VEGF considering the fact that brain is a vital organ that relies on oxygen supply in order to maintain its function. Therefore, it is needed to do a further study to find out the effect of anaerobic physical exercise towards VEGF concentration as an indicator of angiogenesis in Wistar rat brain tissue.

\section{RESEARCH METHOD}

This was experimental study using post test only control group design. This study was conducted in animal house of Faculty of Medicine, Universitas Padjajaran in February 2015. The sample of this study was twenty eight Wistar rats aged from 6-8 weeks and taken using random sampling. The sample was devided into four groups namely P1, P2, P3, and P4. P1 was control group and P2, P3, and P4 were treatment groups. The treatment groups were then given anaerobic physical activities on a treadmill which was set for twenty minutes in speed of $35 \mathrm{~m} /$ minute. The exercise was given in different frequencies; 1 time treatment (P2), 3 times a week (P3), and 7 times a week (P4). The research procedure for anaerobic physical exercises was based on a method developed by Fahrenia and Flora et al [8],[5]. Before the treatments were implemented, all experimental animals were acclimatized for one week by putting them on a low-speed treadmill.

\section{RESULTS AND ANALYSIS}

There was a significant difference in VEGF concentration of brain tissues among groups of one-time treatment $(p=0.044)$, three-times a week $(p=0.034)$, and seven- times a week $(p=0.011)$ if compared with that of control group (Table 1). These findings indicated that anaerobic physical exercise with different frequencies had a significant effect to VEGF concentration of Wistar rat brain tissues.

Table 1. The Effect of Anaerobic Physical Exercise towards VEGF Concentration of Wistar Rat Brain Tissues

\begin{tabular}{lcc}
\hline \multicolumn{1}{c}{ Groups } & $\begin{array}{c}\text { Mean } \pm \text { SD } \\
(\mathrm{pg} / \mathrm{ml})\end{array}$ & $\mathrm{P}$ \\
\hline Control & $63.36 \pm 11.01$ & \\
One-time treatment & $95.21 \pm 31.99$ & 0.044 \\
Three times a week & $47.97 \pm 10.68$ & 0.034 \\
Seven days a week & $40.56 \pm 13.98$ & 0.011 \\
\hline
\end{tabular}

Table 1 shows that there is an increased VEGF concentration of Wistar rat brain tissues in one time treatment group if compared with that of control group. On the other hand, the concentration of VEGF was decreased in treatment groups of three times and seven times a week. The lowest concentration of VEGF was found in a group given seven -time treatment a week.

\subsection{Discussion}

The results of this study showed that there was an increased VEGF concentration of Wistar rat brain tissues in one-time treatment group if compared with that of control group. However, the concentration of VEGF was decreased in treatment groups of three times and seven times a week. This could possibly be explained that in one-time anaerobic exercise there was no body adaptation response to physical exercise given. The body responds this physical exercise as a stressor. The increase of exygen demands during physical exercise will lead to tissue hypoxia. Tissue hypoxia will inhibit oxygen transfer to brain.

Brain is very vulnerable to insufficient supply of oxygen and glucose. In relaxation, our brain needs $20 \%$ oxygen from all oxygen demands and $70 \%$ glucose. The increased demand of oxygen is accompanied by continuous brain metabolic activities. It needs constant blood flow to brain in order to supply adequate and regular nutrients. In one minute, brain needs $800 \mathrm{cc}$ of oxygen and $100 \mathrm{mg}$ of glucose as energy sources [9].

The presence of hypoxia during physical exercises can increase the expression of VEGF through HIF-1 $\alpha$ regulation. The elevation of mRNA VEGF has something to do with the increase of mRNA HIF-1 $\alpha$ 
indicating that HIF-1 $\alpha$ affects the expression of VEGF genes [10]. Similar studies on experimental animals showed that mRNA VEGF of rat muscles was increased four times after single bout treadmill run. The concentration was increased when physical activities were conducted in hypoxic environment [2].

The results of this study were in line with those of Flora $e t$ al in which there was an increased VEGF concentration of cardiac muscle tissues in one-time anaerobic physical exercises [5]. In addition, a study of Margaritescu on patients experiencing acute ischemic cerebral infarct also appealed an increased concentration of VEGF $\left(8.2 \times 10^{3} \pm 7.5 \times 10^{3}\right)$ as a protective mechanism towards stroke hypoxia [11]. The concentration of VEGF was also elevated on motor cortex and striatum of rats which were treated with aerobic physical activities [12].

VEGF is considered as an important angiogenic factor in that the regulation is increased after physical activities and electrical stimuli are given. Therefore, the increase of VEGF provides important stimuli for angiogenesis, especially in initial phase of training program. The VEGF concentration of brain tissue was increased in a treatment group of one-time anaerobic physical exercise [12],[13].

VEGF serves as an important regulator in angiogenesis [14]. Angiogenesis itself refers to the development of new blood cappillaries in responding muscle adaptation to lower level of oxygen. Angiogenesis occurs when there is an imbalance between tissue metabolic demands and the ability of blood vessel perfussion. The regulation of VEGF genes seems to have something to do with exercise intensity, and its concentration is increased significantly in hypoxic condition [2].

In treatment groups of three times and seven times a week the concentration of VEGF was decreased significantly $(\mathrm{p}<0.05)$ if compared with control group. The result of this study was in line with Salceda et al that in acute hypoxia the expression of mRNA HIF-1 $\alpha$ was increased, but in repeated hypoxia the expression of which was decreased again [15]. This result was also supported by a study of Harik et al. In their study, it was stated that vascularisation occurred $45 \%$ in rat brain tissues that experienced hypoxia for one week. However, the vascularisation was not occured in repeated hypoxia [16].

The results of independent $t$-test showed that there was a significant difference $(\mathrm{p}<0.05)$ between VEGF concentration of brain tissues in anaerobic treatment groups if compared with that of control one. Anaerobic treatment with different frequencies affected the VEGF concentration of Wistar rat brain tissues.

\section{CONCLUSION}

The results showed that anaerobic physical exercises performed in different frequencies could influence VEGF concentration of Wistar rat brain tissue.

\section{ACKNOWLEDGEMENTS}

This study was funded by a postgraduate grant from Ministry of Higher Education \& Research and Technology in fiscal year 2015. Therefore, the researcher would be very grateful for the grant so that this study could be finished in time.

\section{REFERENCES}

[1] Bompa, "Total Training For Sport, Plometric for Maximum Power Development”, Oakville, New York, London, Mosuic Press, 1990

[2] Wang, G. L., Jiang, B. H., Semenza, G. L., "Effect Of Protein Kinase And Phospatase Inhibitors On Expresion Of Hipoxia-Inducible Factor-1”, Biochem Biophys Res Commun, vol. 216, pp. 669-75, 1995.

[3] Zhang, E. G., Smith, S. K., Baker, P. N., Charnock-Jones, D. S., "The Regulation And Localisation Of Angiopoietin-1,-2 And Their Receptor Tie2 In Normal And Pathologic Human”, Placentae Molecular Medicine, vol. 7, pp. 624-635, 2001.

[4] Ding, Y. H., Li J., Zhou Y., Rafols J. A., Clark J. C., Ding, Y., "Cerebral angiogenesis and expression of angiogenic factors in aging rats after exercise", Curr. Neurovasc. Res., vol. 3, pp. 15-2310, 2006. $2174 / 15672020677879291$.

[5] Flora, Hans, Joachim Freisleban, Frans Ferdinal, Septelia I, Wanadi, Mohamad Sadikin, "Correlation of hypoxia inducible factor- $1 \alpha$ and vascular endothelium growth factor in rat myocardium during aerobik and anaerobik exercise", Faculty of medicine, UI, Jakarta, 2012.

[6] Kleim, J. A., Cooper, N. R., VandenBerg, P. M., Brain Res, vol/issue: 934(1), pp. 1-6, 2002.

[7] Makanya, A. N., Hlushchuk, R., Djonov, V. G., "Intussusceptive angiogenesis and its role in vascular morphogenesis, patterning, and remodeling", Angiogenesis, vol. 12, pp. 113-123, 2009.

[8] Farenia, R., "Myglobin Gene Expression and Creatinephosphokinase Serum in Anaerobic Physical Activity As An Indicator of Tissue Hypoxia and Tissue Damage in Wistar Rat Muscles", Tesis, Bandung, Universitas Padjadjaran, 2009

[9] Price, S. A., Wilson, L. M., "Pathophysiology: Concepts of Clinical Disease Processes", Vol 2 (6), Jakarta EGC, 2006.

Vascular Endothelial Growth Factor Concentration in Brain of Rat Treated with .... (Rostika Flora) 
[10] Forsythe, J. A., B. H. Jiang, N. V. Iyer et al., "Activation of vascular endothelial growth factr gene transcription by hypoxia-inducible factor-1", Mol. Cell. Biol., vol. 16, pp. 4604-13, 1996.

[11] Otilia Mărgăritescu, D., Pirici, C. L., Mărgăritescu, “Vegf Expression In Human Brain Tissue”, 2011.

[12] Swain R., Harris, A., Wiener E., Dutka M., Morris, H., Theien, B., Konda, S., Engberg, K., Lauterbur, P., Greenough, W., "Prolonged exercise induces angiogenesis and increases cerebral blood volume in primary motor cortex of the rat", Neuroscience, vol. 117, pp. 1037-1046, 2003. 10.1016/S0306-4522(02)00664-4.

[13] Breen, E. C., Johnson, E. C., Wagner, H., Tseng, H. M., Sung, L. A., Wagner, P. D., "Angiogenic growth factor mRNA responses in muscle to a single bout of exercise", J Appl Physiol., vol. 81, pp. 355-361, 1996. [PubMed].

[14] Otani, A., Takagi, H., Suzuma, K., Honda, Y., "Angiotensin II potentiates vascular endothelial growth factorinduced angiogenic activity in retinal microcapillary endothelial cells", Circ Res, vol. 82, pp. 619-628, 1998.

[15] Salceda, S., Caro, J., "Hypoxia-Inducible Factor 1a (Hif-1a) Protein Is Rapidly Degraded by The UbiquitinProteasome System under Normoxic Conditions. Its Stabilization by Hypoxia Depends on Redox-Induced Changes", J. Biol. Chem., vol. 272, pp. 22642-22647, 1997.

[16] Harik, S. I., Hritz, M. A., LaManna, J. C., "Hypoxia-induced brain angiogenesis in the adult rat", The Journal of Physiology, vol. 485, pp. 525-530, 1995. 